questions of the things themselves. They do not care to pull the doll or the toy to pieces: they would rather be told what it is made of than take the trouble to examine it. The element of curiosity seems to have been educated out of them, and their only idea of teaching elementary science is to give the children as many facts as possible about things which they know only by their definitions. Until, then, the present happy generation of children has grown up and become ready to teach science by scientific methods, it seems evident that the plan of itinerant teaching has much to commend it. It is a plan, moreover, whose advantages ought not to be confined to the grammar-schools. Instead of putting a single overworked teacher in charge of all possible sciences in a high school, specialists might be found who would go from school to school, and carry with them an enthusiasm which it is impossible to feel for a very wide range of subjects. The Johns Hopkins university has already tested the excellence of the method for higher schools of learning. It is not impossible that the smaller colleges would gain by it if they were to adopt the plan of making occasional exchanges among their professors. In no other way could they so easily secure the specialization which is necessary for the best teaching.

\section{AN ESTIMATE OF GENERAL GORDON'S SCIENTIFIC CHARACTERISTICS.}

In our eagerness to honor a hero, there is some danger that Gordon's fame may suffer temporary injury, and that his character and the nature of his deeds may be seriously misunderstood. The popular notion seems to be, that he lived in a state of mystical exaltation, and won his strange successes by powers and processes incomprehensible, if not supernatural. Recent writing about him has dwelt so particularly upon his religious fervor, and much of it has been so intemperate and indiscriminating, that it is not strange that some shallow pamphleteers should have classed him with the prophets. He was a hero. Besides that, he was a highly educated, disciplined, and painstaking officer. He inherited military talent, and love for his profession, from generations of soldiers, and he was trained in that thoroughly scientific corps, the Royal engineers. For the first three years of his service under the khedive, he kept careful itineraries of all his marches, and, being a fine topographer, he made solid contributions to our knowledge of the geography of the upper Nile country. I have before me a dozen sketchmaps of the equatorial country, drawn by his own hand with uncommon skill. He was fond of illustrating his letters and memoranda of instructions with geographical and topographical sketches. He was minutely careful in his arrangements for solidifying and extending his communications and positions, fertile and ingenious in applying his knowledge. If we ever learn the details of his defence of Khartum, we shall probably be as much astonished by its mechanical side as by its higher intellectual and moral qualities.

From the beginning of his career before Stevastopol, "He had a personal knowledge of the enemy's movements, such as no other officer attained." His knowledge of the people of the Sudan, of their sheiks and fakirs, and of the Egyptian officers serving there, was remarkable. He had great capacity for detail ; but his mental processes were so rapid, and his perceptions so keen, that he was often thought illogical by those who could not keep up with him. He was often misjudged, too, because he would not bother to explain all his steps.

Far from being a mystic, he was wide awake and practical. In Africa and in China he was constantly vigilant in keeping his powder dry. The clothes, food, pay, and sanitary conditions of his soldiers were diligently watched over. The infirmities of temper of his subordinates were well understood and provided for. His campaign in China may well be studied as a shining example of skilfully planned warfare; and his scheme for the better government of the Sudan involved twelve years of logical and systematic development, before its effect could be fully felt.

Let no one think that Gordon mounted his camel and rode into the desert, or seized his stick and led his rascals up to the mouths of the Chinese cannon, with a magnificent but blind faith. He was a laborious student of the problem in hand, he had a keen intelligence, his judgment was prompt and accurate, he was patient and far-seeing, his will was indomitable ; but, above all, he had eliminated himself entirely from his problem. This made Gordon great. He could see what other men could not, and do what they dared not, because he was as unselfish as a human being can be.

H. G. Provt 